\title{
The Implementation of Character Education Program in Kindergarten
}

\author{
Asep Dudi S, Arif Hakim \\ Postgraduate student at Universitas Pendidikan Indonesia and a lecturer at Faculty of Tarbiyah and Teaching Training \\ UNISBA, Bandung, Indonesia \\ Corresponding e-mail: asepdudi@unisba.ac.id
}

\begin{abstract}
The background of this research is based on the phenomenon of people's behaviour that is more concerned today. This study aims to assess the implementation of character education in kindergarten. Operationally, it includes the aspects of planning, implementing and evaluating. This research is conducted in Negeri Pembina Kindergarten in Bandung through a qualitative approach with case study method. The data collection is done by observation, interview and documentation study. The results show that the planning of the character education program is not a separated program but is an integrated one, into lesson plans that are well documented every day, every week and every year. Character education is implemented through school civilizing character, the field of development daily habituation, and the development of basic capabilities with a model of group learning. Finally. The evaluation of the character education has not used a specific character development-based assessment tool.
\end{abstract}

Keywords: character education, kindergarten

\section{INTRODUCTION}

The Indonesian people are sick, and are being subverted by cancers malignant disease called moral decadence, realizing the condition of the character current society, the government took the initiative to mainstream national character building. This was reflected in the National Long-Term Development Plan for 2005-2025 which puts character education as the first mission of the eight missions in order to realize the vision of national development. Character education should be inculcated from the level of early childhood education, elementary school, high school, and college.

Ministry of National Education in 2010 has developed a formulation of the "Guidelines for the Implementation of Education Culture and National Character". The procedure for its implementation is described in the "Technical Guidelines Implementation of Character Education in Early Childhood Education".

Many experts say that character education should be begun in an early childhood. Why is that? At the early age of 0-6 years, the brain develops very rapidly up to 80 percent. At that age, the brain receives and absorbs various kinds of information. It does not see the good and the bad. That is the period in which the child physically, mentally and spiritually begins to be formed. This period is recognized as a golden period of children (the golden age). It means that the time is perfect for sculpting values (character education) to the children. The efforts of growing character values to the children can be done through character education at home, outside the home, and at the school. One of them is registering the child into an institution of Early Childhood Education.

The character is patterns of thinking and behaving that become hallmarks of each individual to live and work together in the scope of family, community, nation and state. Individual of noble character is the individual who can make decisions in accordance with the norms of life and is ready for the responsibility of each as a result of the decision that he/she made (Saud: 2011). Mustafa (2001) mentions that a person's character is a pattern of behaviour that is supported by the knowledge and love of virtue, and the ability to realize the virtues in daily behaviour. 
This paper focuses on the study of the implementation of character education in a kindergarten of Pembina Negeri in Bandung where more operationally includes aspects of planning, implementation, and evaluation. It is hoped that this article can provide benefits to the practitioners of children's education in order to make a better understanding of the concepts of character education and their implementation; as well as for early childhood teachers, that education implementation is carried out accordingly with the needs of children, not only on cognitive aspect orientation but also on knowing the character development as a fundamental aspect that must be developed at an early age.

\section{RESEARCH METHODS}

This study uses a qualitative approach which seeks to understand the specific situation. Methods of research use a case study that is conducted intensively, deeply and detailed to an organization, institution or certain symptom. In this study, the symptoms are the planning, implementation, and evaluation of character education; as well as the institution is a kindergarten. The data collection techniques are observation, interview, questionnaire, documentation and all three combined (triangulation).

\section{DISCUSSION}

\subsection{The Planning of Character Education Learning}

The planning of character education was done in the early years and it is concurrent with the preparation of the annual program. Lesson plans require a referral or guidelines for the implementation of character education, as well as supporting books that are relevant. In the process, principal of the kindergarten with the teachers deliberate the values that be given as priority in the development of character values at the kindergarten. That values are adapted to the degree of urgency, social and cultural conditions, as well as the availability of facilities and infrastructure that supports the development of character values, in order to become more optimal and, of course, accordance with the stages of child development. The learning plan then was made in the form of a syllabus which is a set of plans and learning activities, classroom management, and assessment of learning outcomes. The syllabus contained also the form of annual planning, as well as weekly and daily planning.

The meeting of principal and the teachers decided that there are five characters to be priorities in the development of character value: religious, creative, patriotism, curiosity, responsibility. This character values will be incorporated into an integrated learning activities plans.

The planning includes annual and semi-annual components: standards of competence, learning outcomes, development of indicators, themes, and the estimated time of the week. The plans are prepared jointly by the principal with the teachers at the beginning of the new school year and then are translated into the weekly plan. When drawing up the semester program at the beginning of the school year, principals with teachers prepare 'Translation of the charged Indicators Arts and Character'. This guide is intended as the basis for the teachers when preparing the Daily Activities drafts. The changes which occur on a draft of daily activities in each classroom or each group lies in the development of activities as well as media which will be used by each teacher in the classroom.

Weekly planning manifested in a Weekly Activity Plan. It contains themes, sub-themes, and the scope of the development to be achieved by students in learning activities. This plan serves as a referral for teachers to develop learning activities and its elements so that the implementation of learning will be easier and more effective. In the planning of weekly activities, material and form an integrated poured activities that target the entire scope of children's developmental, as well as the achievement level of child development. As a complement, aspects of character development, especially the values that will be developed in the week, are entered as an integrated material. For example, religious values, independence, responsibility, hard work, self-celebrants, curiosity, and others.

Daily planning is arranged in the form of Daily Activity Plan that includes learning activities, whether carried out individually, as a group, as well as classical in one day. It contains components: values of character education and entrepreneurship, indicators, learning activities, props / learning resources, assessment tools and development outcomes. Daily planning is constructed within the scope of the initial activity, core activities, and closing activity.

Referring to the Technical Guidelines for the Implementation of Character Education in Early 
Childhood developed by the Directorate General of Education Early Childhood Education, Non-Formal, and Informal. (2012), the output of the planning that occurs in institutions that were studied were: (1) the circumstances, physical environment, social environment, emotional environment, and cultural environment in the school environment is conditioned so that learners and other school communities accustomed to making daily activities that reflecting the embodiment of the value (character). This includes interaction between students, students, and teachers, between teachers and the school community with the surrounding community. One example of creating a physical environment that supports the religious character is the provision of prayer rooms at the back of the school, ablution facilities, quotations from sacred texts on the walls of the classroom, as well as letters and writing the names of God.

Character development is seen on the availability of trash cans throughout the school environment that is easy to use by learners; handicraft of students were attached to the wall that has been provided to every student at one part of the school; tools of educational games that are relatively complete provided both inside and outside the classroom; there is also a school library, tools of extracurricular activities: drum band tools fully set, and a full set of angklung instruments.

Social and emotional relationship between the school community is seen from: the principal's leadership through his attitude, manner of speaking and behavior that has been demonstrated, for example, when he spoke to the teachers, they looked very concerned and carry out his directives as well as possible; the teachers who demonstrate a friendly attitude towards learners, for example, say good words, speak politely, and always say the word "please" as a companion requests or commands to the learner; then, the relationship between the teacher looks of mutual respect and mutual help.

Then in terms of socio-cultural which is reflected in the culture of the school in Negeri Pembina Kindergarten, it is mentioned that every sign of the child's school is only delivered to the front of the school and then the teacher greets the class and shakes her/his hand, even so, when the teacher tells students that the class is over, the children go to the principal's office and move, shake hand with the headmistress of the one. Then there are particularities made every day as character education in schools that serve the planting of character values.
(2) Management of the classroom. The form of management as the supporting implementation of character education in kindergarten Pembina Negeri is the provision of facilities and infrastructure support

The arrangement of the room and display of images by learners in the form of the work performance of the children, and teachers in the form of drawings or writings that have education for students is important to note because this will support the implementation of character education in schools better.

Condition net class is also the form of habituation to the learners to always maintain personal hygiene and the environment, which is one of the applications the value of its responsibility to maintain the cleanliness, comfort and order environment. In its management for each class is handed to each homeroom in organizing the classroom, in order to be comfortable and conducive to learning.

(3) Character Education Strategy practice. Efforts are being made to the planning of character education in kindergarten Pembina Negeri in order to develop a strategy in the practice of character education through the development of school culture and development of activities habituation.

The implementation is done through selfdevelopment activities including routine, spontaneous activities, the exemplary, and conditioning. The things are as follows. (a) Routine, the routine is a routine activity is done at any time. Routine activities can also mean student activities continuously and consistently every time. Some examples of the routine activities e.g. ceremony Monday, hygiene inspection bodies, picket class, Duha prayer in congregation, line up when entering the classroom, praying before class begins and ends, and greeting when meeting the school principal, teachers, educators. (b) The activities of spontaneous, spontaneous activity can also be called incidental activities. This activity is done spontaneously without prior planning. Examples of these activities are to help friends who are in need of relief aid, tidying tool after playing a game, social work at an orphanage, celebrating a birthday, and give a birthday present when birthdays. (c). Modelling, modelling is an attitude of "be an example". This attitude is the behaviour of the attitude of principals and teachers in providing an example through good actions so that this is expected to be role models for other students. 
Examples of these activities e.g. personal example teachers become clean, polite, tidy, friendly, and sociable and smooth-spoken. (d) Conditioning, conditioning is associated with the efforts of schools to organize physical and non-physical environment in order to create an atmosphere to support the implementation of character education. Organized activities for example physical environment are conditioning the clean restrooms, trash, green courtyard with trees, posters wise words on display in the halls and in the classroom. While conditioning the non-physical environment such as managing conflicts between teachers so that no discord, or even eliminate the conflict. (e) Extracurricular activities, extracurricular activities are activities outside learning activities. Although outside learning activities, teachers can also integrate it into their teaching. In Negeri Pembina kindergarten, a lot of extracurricular activities for students are related to the number of activities outside, such as marching band, dance, and angklung. (f) The daily activities at home and in the community, this activity is a supporting activity of character education in schools. House (family) and community are important partners for the successful implementation of character education in schools. Implementation of character education as good as any, if children are not supported by the family environment and the community will be in vain. In this activity, the school may seek the creation of harmony between the characters are developed at school by habituation in the home and community. The efforts made by kindergarten Negeri Pembina is the cooperation between parents and schools in developing and educating children through the cooperation of the schools with the School Committee, led by representatives of the parents, it means that there is an understanding that goes along here. So, the values taught by teachers in schools should be followed by parents at home, and not the reverse unsupported causing counter-productive in educating children.

\subsection{Implementation of Character Education Learning}

The implementation of learning activities at the level of kindergarten - childhood as usual i.e. opening activities, the core activities, the activities of eating and resting, and the closing. Character education in kindergarten occurs implicitly in learning activities, meaning the character education program is integrated into the daily learning activities and are not taught specifically for one day, for example. Character education activities here occurs through synergy between teachers, students and learning environment that supports the creation of character education in it. Character education in kindergarten is an activity habituation repeatedly performed by students who have lofty moral values, religion, and nationality. These learning activities are carried out from the start at 08:00-11:00 am, from Monday until Friday.

The form of character education is started with the entrance to the school or class. Here, the child when beginning to go to school or class is only accompanied by parents up to the front gate. They are planting the value of responsibility namely independence in children too. This is done according to the agreement between parents and teachers in order to deliver the child to the gate at the beginning of the school year. Furthermore, children lined up in front of the school together with teachers, children here are given wholly conditioning to be ready to learn today to greet the children, pray before studying with together and the songs of the spirit of the morning. Furthermore flag ceremony (Monday) or direct the children go to class (Tuesday-Friday), with the first children's greetings to the teacher and the teacher greeting and kissing each other. Here are the religious values that developed when praying together, the value of patriotism during the flag ceremony and discipline and tolerance at the time lining up and shaking hands.

Opening activities begin with prayer. Here, the child will read a prayer before studying together in class while sitting in a circle, then continue with the activities to break the ice so that children are better prepared to learn to sing children's songs and clap. The kindergarten Negeri Pembina, there are religious values and honest values developed in them. Furthermore, given a persepsis about themes that will be given at the time of learning activity, for example, in the example attachment (sports theme) by showing the layout (picture) conditions of mountainous regions, sea, paddy fields, tea gardens, on the beach and in the countryside.

The method used is storytelling, here the teacher seeks to stimulate the creativity of children with a question and answer, such as what children see in the picture? then the activity what is done in the picture?, then anyone who is involved in the picture?, anywhere the place shown in the picture?. It can stimulate children to ask questions or share the experience they have ever experienced anywhere in 
the pictures, as some children who have been to the village, to the beach, then played to the fields or to the tea garden and what is seen and experienced by them, as well as with whom they play there. Here, the value of curiosity and confidence develops when the children courageously speak in front of their friends. Both of these values the curiosity and confidence will be developed at the beginning of each child's learning though the theme is different, but the meaning of these values which want to continue to develop and become a good character for children in the future.

The next activity is at core activity, which in the core activities of kindergarten Negeri Pembina is a model group with a safety. In the implementation, there are three core activities in it which every form of activity represents the scope of the development i.g language development, cognitive and physical motor. In all activities, a lot of character values are developed, for example, the value of creativity, confidence, responsibility, independence, tolerance and others, depending on the context of the development activities of each sphere of development.

Further break and meal. Planting of character values in this activity is very meaningful, whereby when the children will begin to eat the children familiarized to praying (religious value) then when the meal was later discovered there are children who do not have meal times, then the children are taught to share with others friends (tolerance), then before feeding children familiarized of washing hands and after a child's eating familiarized, they are asked to tidy up everything to be placed to the previous original position (the value of responsibility) which are developed. The last at the closing, children are invited to explain the resumption of what has been done before. Children are invited to recall, then the value of creativity and hard work, which children need these characters when adulthood.

\subsection{Character Education Learning Assessment}

Assessment of learning in early childhood is a systematic procedure used to obtain information about the performance or progress of various aspects of development that can be achieved by learners after the following study within a certain time.

Relation to character education, character education assessment aims to find out the extent to which changes in attitudes and behaviour of children after following activities are loaded with character values. Continuous assessment activities carried out in order to change attitudes and behaviour can be viewed as a whole.

Aspects that are used as a developmental assessment of character values in TK Negeri Pembina include the entire value of 18 characters contained in the character values proclaimed by the government. However, in fact, it is adapted to the circumstances in each environment. As in the kindergarten Negeri Pembina, there are five aspects are a set of priorities in the development of character, such as Religious, Creative, patriotism, curiosity, responsibility. However, this does not restrict the development of the values other characters, the fact is that in a daily learning, the values other characters will certainly be developed, like for example, self-reliance, honesty, and tolerance.

In the assessment of learners, the kindergarten Pembina Negeri is not specifically found an assessment instrument is special about the character values education in early childhood. The assessment of the characters in this kindergarten is still using the assessment development of learners as a usual. The Rating of five aspects of development includes religious values and moral, cognitive, language, social, emotional, physical and motor. So that the values of character that have been developed in children, an element of judgment merges with the assessment of the five aspects of the development.

\section{CONCLUSIONS}

The application of character values in kindergarten performs in exemplary form, habituation, and the daily repetition. The planting of character values in children is not demanding a submission, but it should be realized and believed by children so that they are able to know what is right and wrong and integrated into his heart to believe in it so it can be internalized in their conscience.

Character education in kindergarten needs to be implemented in integrated learning through the development of habituation and development activities especially wrapped in a theme of learning.

The planning of character education programs in kindergarten consequently and consistently integrates vision since kindergarten until in the Activity Plan Weekly and Daily Activity Plan Implementation of the character education program conducted through the internalization of character values in learning activities by adopting the model in groups with safeguards considered appropriate, since 
this model can create an effective learning and fun and stimulate multiple bits of intelligence of children with a child as the learning center. Assessment learning achievement of character education in kindergarten requires instruments regarding developmental assessment of children characters individually, even temporarily it can also be combined with the assessment of child development in general like the development of moral and religion, physics, and motor, cognition, linguistics, social and emotion of children.

\section{REFERENCES}

Dirjen Pendidikan Pendidikan Anak Usia Dini, Nonformal dan Informal. (2012). Petunjuk Teknis Penyelenggaraan Pendidikan Karakter Pada Anak Usia Dini. Jakarta. Kemendiknas.

Kementrian Pendidikan Nasional. (2011). Pedoman Pelaksanaan Pendidikan Karakter (Berdasarkan pengalaman di sekolah rintisan). (2011). Jakarta. Puskurbuk.

Kementrian Pendidikan Nasional. (2010). Pengembangan Budaya dan Karakter Bangsa, Jakarta. Puskurbuk.

Mustofa, Bacharudin. (2011). "Karakter sebagai Saripati Tumbuh Kembang Anak, Beberapa Persyaratan Esensial bagi Keberhasilan Implementasi Program Pendidikan Karakter bagi anak Usia Dini”, dalam Karakter sebagai Saripati Tumbuh Kembang Anak. Yogyakarta. Inti Media.

Saud. U.S. Prof.Ph.D.(2011). Revitalisasi Pengelolaan Pendidikan Dasar untuk Fasilitasi Pendidikan Karakter yang Mulia dan Kokoh Bagi Generasi Masa Depan. [online]. Dapat diakses di :

http://adejuve.wordpress.com/2011/10/22/pend idikan-karakter-mulia-yang-kokoh/ 